\title{
Remittance and its Impact on Nepalese Economy
}

\section{Rajan Katuwal Chhetri*, Prabhat KC and Shiva Chandra Dhakal}

Department of Agricultural Economics and Agribusiness Management, Agriculture and Forestry University, Nepal

*Corresponding Author: Rajan Katuwal Chhetri, Department of Agricultural Economics and Agribusiness management, Agriculture and Forestry University, Rampur, Chitwan, Nepal.

DOI: 10.31080/ASAG.2020.04.0818
Received: February 21, 2020

Published: February 28, 2020

(C) All rights are reserved by Rajan Katuwal Chhetri., et al.

\begin{abstract}
This paper assesses the current remittance status and its impact on Nepalese economy. Secondary data from various sources were used for study. Statistical techniques including descriptive statistics and correlation was used. The number of Nepalese citizen for foreign employment is increasing year after year. Malaysia is the primary destination of Nepali migrants followed by Qatar, Saudi Arabia, UAE and others respectively. Nepal ranks $19^{\text {th }}$ position in top remittance receiving countries of the world and it ranks 4 th position when remittance is compared as a percentage of GDP. Percentage increase in inflation was lower in comparison with the proportion of remittance as compared with GDP. Result showed insignificant relationship between remittance inflow and increase in agricultural land. Remittance has played several positive roles in Nepalese economy like reduction of poverty and unemployment, maintaining foreign exchange reserve and correcting balance of payments. Positive and significant correlation was found between GDP and remittance inflow per year at $10 \%$ level of significance. Remittance as compared with percentage of GDP and share of agriculture, forestry and fishing were negatively and significantly correlated. The share of agriculture, forestry and fishing to GDP of country was found to be diminishing but proportion of remittance when compared with GDP was increasing. Problem of labor shortage in agricultural as well as non-agricultural works is a genuine problem as active youths are involved in foreign employment. As volume of remittance is being increased rapidly, dependency of people on remittance is increasing and Nepalese economy is gradually becoming consumption oriented. Also, Nepalese economy is transforming from agriculture based economy to remittance based economy. So, formulation and implementation of appropriate policies which tap and utilize received remittance into productive sector is recommended.

Keywords: Economy; Employment; GDP; Poverty; Remittance
\end{abstract}

\section{Introduction}

Remittance is that part of earning sent by individuals from migration destination to their home country or their place of origin, which is a vital source of foreign income for developing countries like Nepal. Although remittance can be sent in the form of kind but the term usually limited to represent monetary and cash transfers sent by international migrant workers to their place of origin [1]. Remittance covers large portion of financial flows to developing countries like Nepal. Remittance is important source in labour exporting countries to maintain foreign exchange reserve and to correct Balance of Payments. Remittance implies household income from foreign inflow mainly from momentary or permanent migration of people to those economies [2]. According to World Bank [3] remittance enables households to increase their level of consumption, ensure better health facilities, nutrition, education and other facilities.

In developing countries, remittance is three times more than official development assistance [4] and it ranks second largest source of external finance after foreign direct investment [5]. Remittance is important to economies at micro as well as macro level. The impact of remittance on macro economic level is found to be qualitative [6]. For the countries that are affected by political and economic crisis, remittance is regarded as important and stable source of external finance [7]. In such countries, as compared with other capital flows like official development assistance and foreign direct investment, remittance is one of the most secure and consistent sources of foreign currency. In micro level, remittance has helped in enhancing livelihood by acting as alternative source of income to the poor and marginalized people [8]. Remittance has significant role in poverty alleviation. Remittance has not only affected welfare and capacities of household receiving remittance but also of the entire community [9]. Remittance has become important international financial flows in the last few years. Remittance has surpassed official and private capital flows [10] and it equals to about US $\$ 444$ billion which is about three times than the official aid and equivalent to foreign direct investment flows to developing countries.

The main reason for foreign employment is attributed to slow performance of production and non-productive areas, population growth, political instability, varying attitude of people towards livelihood. Due to liberalization and globalization, youths of Nepal started to migrate for foreign employment for economic and noneconomic causes [11]. Ministry of Finance (2011) reported that 250,000 people annually leave country in search of employment opportunities. Nepalese economy is, now, changing from agriculture based to the remittance based as majority of active working 
population is in foreign employment. Foreign migration may adversely affect agricultural yield but it can boost up the capacities of remittance receiving household to obtain productivity enhancing capital which will finally increase yield [12]. Chiodia, Jaimovichb, and Montes-Rojasc [13] also reported remittance boost household capacities to spend on productivity enhancing human and physical assets.

According to Ratha (2015), Nepalese economy is becoming more remittance dependent due to continuous growth of remittance inflow. Due to low economic return from agriculture, rural population is now switching over other occupations. The largest number of Nepalese for foreign employment are in Malaysia (30.1\%) followed by Qatar (27.4\%), Saudi Arabia (20.2\%), United Arab Emirates (13.1\%) and others (9.2\%) respectively [14]. While taking account of the remittance as a percentage of GDP Nepal ranks fourth position in top remittance receiver countries of the world whereas it ranks first in South Asia [15]. Foreign employment and remittance is major economic phenomenon in Nepal, but sustainability of Nepalese economy with remittance based economy is questionable. Though the volume of remittance is increasing, it is being used for consumption and loan repayment and very less portion is used in productive sector. Positive impact of remittance to alleviate poverty is a well known fact but other non-pecuniary consequences like impact on health, education, gender issues, politics, social and cultural changes in society is not well known yet. Utilization of remittance in unproductive sectors, low rate of economic growth, inadequate employment opportunities, brain-drain etc. are burning issues of current Nepal. Although, remittance plays a vital role in Nepalese economy, very few studies have been done to understand impact of remittance in Nepalese economy.

Even though, volume of remittance is increasing, investment has not been improved up, acquisition and distribution of technology is inadequate and brain drain is growing every day. This study tries to look into major issues which are influenced by remittance. The findings of this study can be used as guiding tool to policy makers. The general objective of this study is to assess the impact of remittance in Nepalese economy. The specific objectives are to study current status of remittance in Nepal and contribution of remittance in Nepalese economy.

\section{Materials and Methods}

This paper is based on secondary data collected from different national and international institutions. Majority of data used in the study are obtained from Economic survey of Ministry of Finance, CMEs annual tables of Nepal Rastra Bank, Remittance data from World Bank, Migration and Remittances by World Bank group. Descriptive statistics, trend analysis and correlation were used in the study [16].

\section{Results and Discussion}

Remittance inflows in the world

India is the top remittance receiver country in the world $(\$ 79.5$ billon) followed by China ( $\$ 67.4$ billion), Philippines ( $\$ 33.7$ billion), Mexico ( $\$ 33.7$ billion). Nepal received $\$ 8.2$ billion remittance

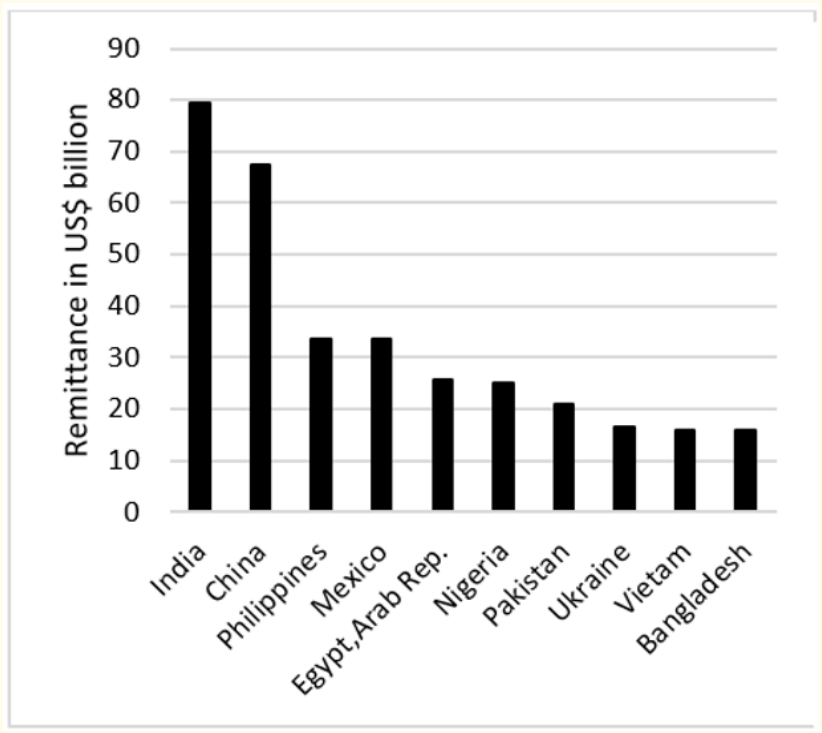

Figure 1: Top remittance receiving countries of world. Source: International Monetary Fund, World Development Indicators, World Bank Staff estimates.

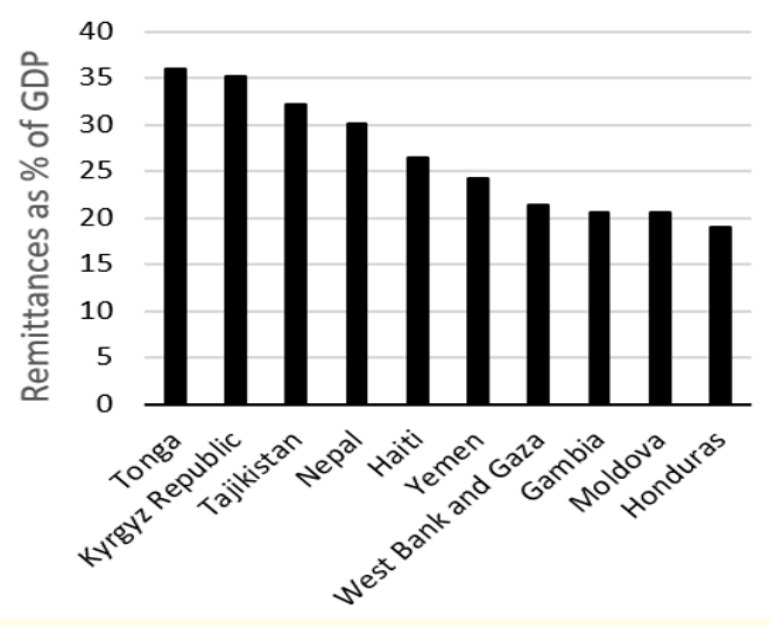

Figure 2: Remittance as \% of GDP.

Source: International Monetary Fund, World Development Indicators, World Bank Staff estimates.

and ranks 20th position in the world. Whereas, as a percentage of the GDP Tonga is the top remittance receiver (35.9\%) followed by Kyrgyz Republic (35.1\%), Tajikistan (32.2\%), Nepal (30.1\%) and Haiti (24.2\%) [15].

\section{Remittance inflows to South Asia}

India is the highest remittance receiving country in South Asia ( $\$ 79.5$ billion), followed by Pakistan ( $\$ 20.9$ billion), Bangladesh ( $\$ 15.9$ billion), Nepal ( $\$ 8.2$ billion), Sri Lanka ( $\$ 7.6$ billion) and Bhutan ( $\$ 0.4$ billion) respectively. Whereas, when remittance is compared as a percentage of GDP Nepal ranks first position in remittance receiving countries of South Asia (30.1\%) followed by Sri Lanka (8.1\%), Pakistan (6.9\%), Bangladesh (5.6\%), India (2.8\%), Bhutan (1.9\%), Afghanistan (1.8\%) and Maldives $(0.1 \%)$ respectively. 


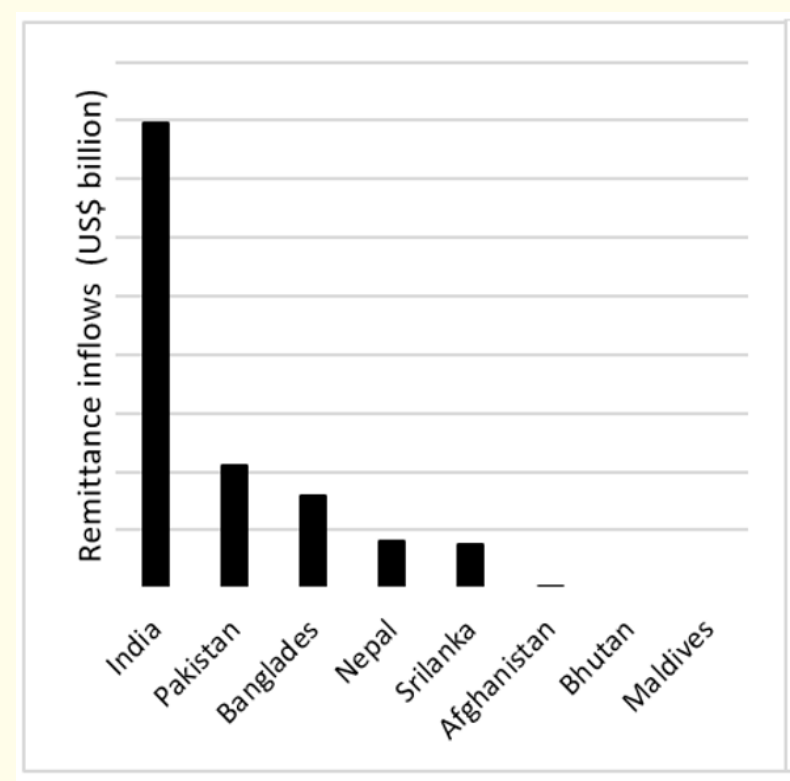

Figure 3: Remittance inflows to South Asia. Source: IMF, World Development Indicators, World Bank estimates.

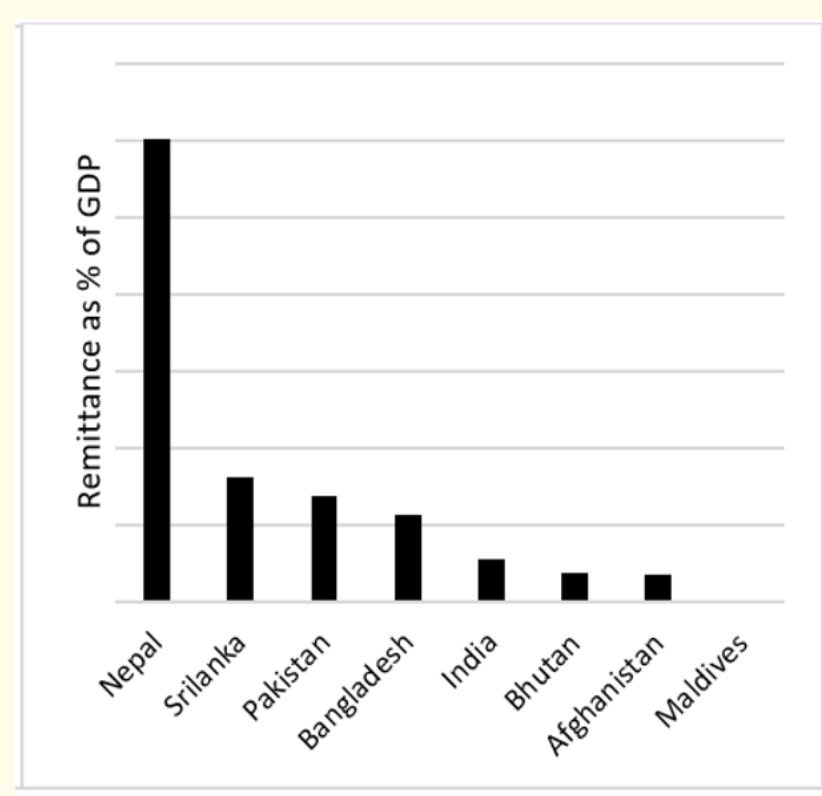

Figure 4: Remittance inflow to South Asia as \% of GDP. Source: IMF, World Development Indicators, World Bank estimates.

Country wise status of Nepalese workers in foreign employment

Malaysia is the destination of maximum number of Nepalese workers $(30.1 \%)$ for foreign employment. Similarly, Qatar ranks seconds where $27.4 \%$ of Nepalese workers have gone for foreign employment followed by Saudi Arabia (20.2\%), United Arab Emirates $(13.1 \%)$ and Others (9.2\%). Nepal government has permitted for foreign employment in institutional form in 110 countries. While Nepalese have gone in 172 countries on individual working license. Working license permit for Iraq and Libiya has been cancelled for now. From fiscal year 2066/67 to 2075/76 Falgun, about $45,40,906$ Nepalese have obtained working license.

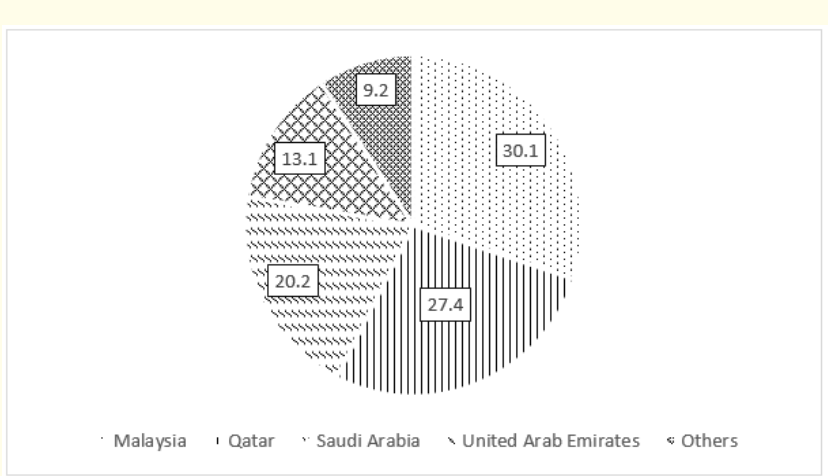

Figure 5: Nepalese workers in foreign employment by country. Source: Ministry of Labor, Employment and Social security and foreign employment department.

GDP and remittance inflow

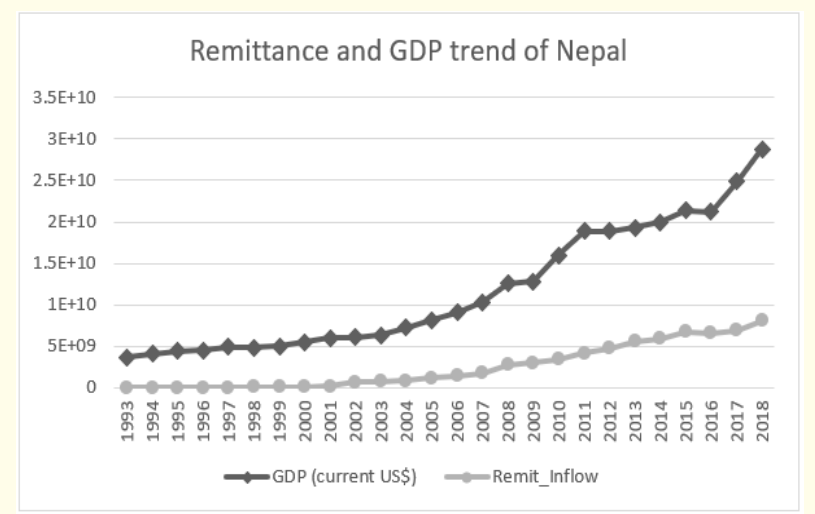

Figure 6: Relationship between remittance and GDP of Nepal. Source: World Bank, World Development Indicators.

Comparison between GDP of Nepal and remittance inflow shows that the trend of both GDP as well as remittance inflow is increasing. Correlation study between GDP and remittance inflow shows positive $(r=0.9903)$ and significant relationship between the two variables at $10 \%$ level of significance. It indicates that with the increase in remittance inflow, there is increase in GDP of the country. Due to the positive influence of remittance on consumption, saving and investment, remittance might contribute to economic growth. Giuliano and Ruiz-Arranz (2005) also found remittance might accelerate economic growth by improving credit constraints, improving capital allocation and acting as substitute for the lack of financial development. Meyer and Shera [17] also found worker's remittance contribute positively and significantly to the economic growth but the productive use of remittance can help improving the economic growth of the countries by investing that money into consumption and investment. Remittance have both positive and negative effects on economy. Thagunna and Acharya [18] reported that remittance and grants has positive effect to raise nominal GDP in Nepal. Remittance affect both household and national scale development and it contributes to the national economy [19]. Neupane (2011) revealed that remittance not only increases consumption but it also enhances gross domestic product. Gaudel [20] found remittance income and grants as relevant factors to increase GDP in Nepal. Similarly, in a study conducted by Malekoo [21], re- 
sult showed positive and significant effect of remittance inflow on GDP and deposit of commercial banks.

\section{Agricultural land and remittance inflow}

Correlation study was done between agricultural land in square kilometers and remittance inflow per year. There was positive ( $r$ $=0.29$ ) but insignificant correlation at $\alpha=0.10$ between the two variables. It shows that with the increase in remittance there is no further increase in agricultural land. It might be due to as people migrate for foreign employment, the availability of manpower for agricultural work decreases and there is no further exploration of land for agriculture use. Agricultural land increases when land used for other purposes like forest, pastures etc. are converted for agricultural purposes. But as large number of labor migrate for foreign employment, there is not such transformation of land into agricultural use.

\section{Inflation and remittance}

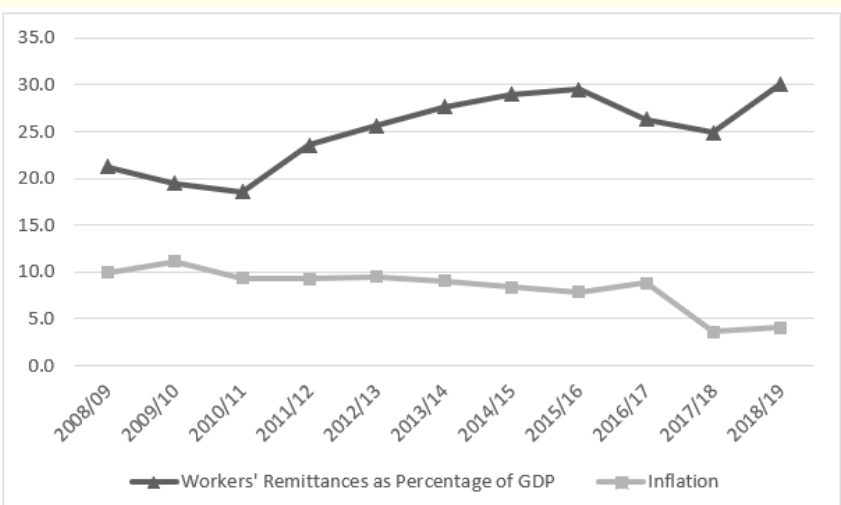

Figure 7: Worker's remittance as \% of GDP and Inflation rate. Source: World Bank, World Development Indicators.

Worker's remittances as percentage of GDP and inflation was studied which showed that the percentage of remittance when compared with GDP is more than the inflation rate. Worker's remittance was found to be increasing annually from 2008/09 to 2015/16 but proportion of remittance to GDP was reduced in $2016 / 17$ and 2017/18. The proportion of remittance again increased in 2018/19. Similarly, rate of inflation was almost similar from $2009 / 10$ to $2016 / 17$ but it was lower in $2017 / 18$ and 2018/19. In 2017/18 both the remittance and inflation are low. Tung., et al. [22] also found positive relationship between inflation and remittance. Roy and Rahman [23] concluded that there is inflationary pressure of remittance inflows in Bangladesh and food inflation is about 2.5 times more than the higher inflation. Rodrik [24] also found rise in remittance inflow results underestimation of long-term economic growth by overvaluating real exchange rate which will induce inflationary pressure.

Comparision of remittance with agriculture, forestry and fishing

Trend of remittance as percentage of GDP was found to be increasing whereas conversely, trend of share of agriculture, forestry and fishing is found to be decreasing. When remittance as percentage of GDP and share of agriculture, forestry and fishing are analy-

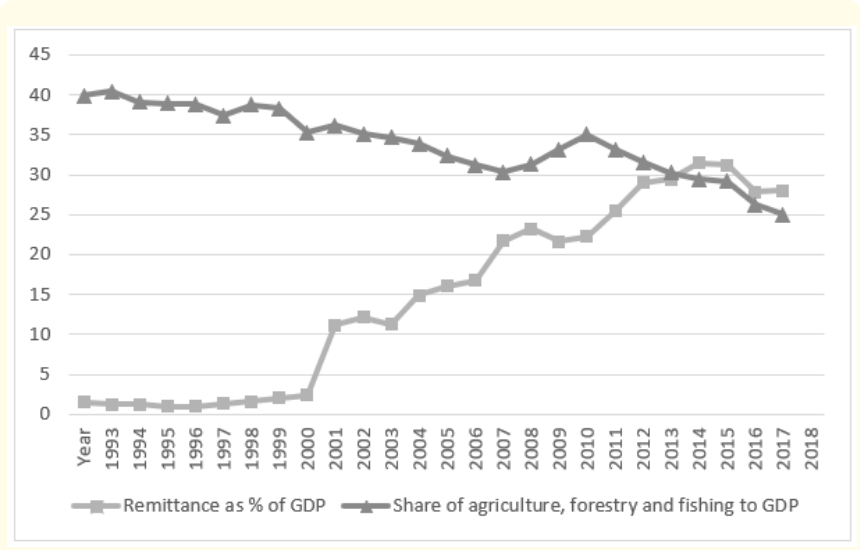

Figure 8: Remittance as \% of GDP and share of agriculture, forestry and fishing in \%.

Source: World Bank, World Development Indicators.

syed, there was statistically significant (at $\alpha=0.10$ ) and strong negative correlation $(r=-0.8975)$ between the two variables. This indicates that with the increase in the proportion of remittance when compared with GDP, share of agriculture, forestry and fishing is decreasing. Increase in the number of Nepalese people in foreign employment and subsequent increment in the remittance inlfow might have increased the income as well as the consumption capabilities of household receiving remittance. So, household receiving remittance might not practice agriculture and related activites as compared with the households which do not receive recmittance. Those remittance receiving household would either depend on either the remittance income or they prefer other occupations like business. So, with increase of remittance, the share of agriculture, forestry and fishing is found to be decreasing gradually. Gartaula., et al. [25] reported that rising trend of foreign migration and youth reluctance towards agriculture have caused gradual shifting of agriculture based economy of Nepal to the economy based on other sources of income along with remittances which threatened the food security and agricultrual sector. Dhungana [26] also reported that heavy reliance on remittance has shifted Nepalese economy from agriculture based to remittance based economy. ADS [27] reports that as youths are choosing employment options other than agriculture, there are women, old and children left in villages. This will hinder increment in agricultural land and agricultural production $[28,29]$.

\section{Conclusion}

With increasing globalization and liberalization, trend of foreign employment is increasing resulting in rapid growth of remittance received by Nepal. It is found that with the increase in the remittance inflow, there is no further increment of agricultural land. The share of agriculture, forestry and fishing to GDP is found to be decreasing whereas proportion of remittance to GDP is gradually increasing. Due to large number of active youths working abroad, there is problem of labor shortage for agriculture and other works. It also has resulted dependency of families on remittance income. Nepalese economy is gradually transforming into consumption oriented economy due to remittance, resulting more imports. Proportion of remittance as compared with GDP is more compared 
with the percentage increase in rate of inflation. The rising trend of youth migration for foreign employment and dependency of remittance has resulted positive as well as negative impact on Nepalese economy. Remittance and GDP showed positive relationship. Foreign employment and thus remittance has played significant role in reduction of poverty and unemployment. Remittance is important source of foreign currency in Nepal. So, government should formulate and implement policies which tap and utilize remittance received in Nepal into productive and investment sectors. Government should provide appropriate investment climate to invest remittance income. Formulation and implementation of appropriate remittance policy can help in boosting up Nepalese economy.

\section{Bibliography}

1. Neupane NK. "An analysis of impact of remittance on Nepalese economy". TU, Nepal: Department of Economics (2018).

2. IMF. "Balance of payment and international investment position manual" (2009).

3. World Bank. Resilience Amidst Conflict: An Assessment of Poverty in Nepal, 1995/96 - 2003/04, Washington, D.C: World Bank (2005).

4. World Bank. "Monthly and Quarterly Remittances Flows to Selected Countries". Washington, DC: World Bank (2015).

5. Ahamada I and Coulibaly D. "Remittances and growth in subSaharan African countries: Evidence from a panel causality test". Journal of International Development 25 (2013): 310324.

6. Arranz M and Giuliano P. "Remittances, Financial Development, and Growth". IMF Working Paper (2005).

7. Kapur D. "Remittance: The New Development Mantra?" United Nations Conference on Trade and Development. Geneva (2003).

8. NRB. "Impact evaluation of remittances: A case study of Dhanusha district". Janakpur: Banking development and research unit (2012).

9. de Haas H. "Remittances, Migration and social Development: A Conceptual Review of the Literature". Programme on Social Policy and Development. UNRISD, Geneva (2007).

10. Giuliano P and Ruiz-Arranz M. "Remittances, Financial Development, and Growth". Journal of Development Economics 90 (2019): 144-152.

11. Bhatta G. "Remittance and trade deficit nexus in Nepal: A VECM approach". NRB Working Paper (2013).

12. Stark 0. "On the Role of Urban-to-Rural Remittances in Rural Development”. Journal of Development Studies 16 (1980): 369364.

13. Chiodia V., et al. "Migration, Remittances and Capital Accumulation: Evidence from Rural Mexico". Journal of Development Studies 48.8 (2012): 1139-1155.
14. MoL. (2018/19). Economic survey. MoL (2016).

15. KNOMAD. Migration and Remittances: Recent development and outlook (2018).

16. Rastra Bank. CMRa annual tables 2017/18 (2018).

17. Meyer D and Shera A. "The impact of remittances on economic growth: An econometric model”. EconomiA.

18. Thagunna $\mathrm{K}$ and Acharya S. "Empirical analysis of remittance inflow”. Economics and Financial 3 (2013): 337-344.

19. Pant. "Harnessing Remittances for Productive Use in Nepal". Economic Review 1-20 (2011).

20. Gaudel Y. "Remittance Income in Nepal: Need for Economic Development". The Journal of Nepalese Business Studies 3.1 (2006).

21. Malekoo R. "Impact of remittance on deposit of commercial banks' and economic growth of Nepal". MBA Dissertation (2015): 1-76.

22. Tung L., et al. "The impact of remittance inflows on inflation: Evidence in asian and the pacific developing countries". Journal of Applied Economic Sciences 10 (2015): 1076-1079.

23. Roy R and Rahman M. "An Empirical Analysis of Remittance Inflation Relationship in Bangladesh: Post-Floating Exchange Rate Scenario". Bangladesh: Munich Personal RePEc Archive (2014).

24. Rodrik D. "The real exchange rate and economic growth". Brookings Papers on Economic activity (2008): 365-412.

25. Gartaula H., et al. "Shifting perceptions of food security and land in the context of labour outmigration in rural Nepal". Food Security 4.2 (2012): 181-194.

26. Dhungana B. "Remittance and Nepalese economy" (2011).

27. ADS. "Agriculture Development Strategy (ADS) 2015 to 2035". Kathmandu, Nepal: Ministry of Agricultural Development, Singh Durbar (2015).

28. Central Bureau of Statistics. (2003/04). Nepal Living Standards Survey. Kathmandu: CBS.

29. de Hass H. "Migration, Remittances and Regional Development in Southern Morocco". Geoform 37.4 (2006): 565-580.

\section{Assets from publication with us}

- Prompt Acknowledgement after receiving the article

- Thorough Double blinded peer review

- Rapid Publication

- Issue of Publication Certificate

- High visibility of your Published work

Website: www.actascientific.com/

Submit Article: www.actascientific.com/submission.php

Email us: editor@actascientific.com

Contact us: +919182824667 